REGARDS

SUR L'ECONOMIE ALLEMANDE

BULLETIN ECONOMIQUE DU CRAC

\section{Regards sur l'économie allemande}

Bulletin économique du CIRAC

$87 \mid 2008$

Varia

\title{
Sciences politiques
}

LADEUR Karl-Heinz, Der Staat gegen die Gesellschaft

\section{(2) OpenEdition}

\section{Journals}

Édition électronique

URL : http://journals.openedition.org/rea/989

DOI : $10.4000 /$ rea.989

ISBN : 978-2-8218-0870-6

ISSN : 1965-0787

\section{Éditeur}

CIRAC

\section{Édition imprimée}

Date de publication : 1 juillet 2008

ISSN : 1156-8992

Référence électronique

"Sciences politiques », Regards sur l'économie allemande [En ligne], 87 | juillet 2008, document 4, mis en ligne le 08 juillet 2008, consulté le 22 septembre 2020. URL : http://journals.openedition.org/rea/ 989 ; DOI : https://doi.org/10.4000/rea.989

Ce document a été généré automatiquement le 22 septembre 2020

(C) CIRAC 


\section{Sciences politiques}

LADEUR Karl-Heinz, Der Staat gegen die Gesellschaft

\section{RÉFÉRENCE}

LADEUR Karl-Heinz, Der Staat gegen die Gesellschaft, , Mohr Siebeck, Tübingen, 2006, $448 \mathrm{p}$.

1 Crise de confiance dans l'Etat, impuissance grandissante de l'Etat à appréhender un rôle en adéquation avec l'évolution de la société... L'auteur de cet ouvrage interdisciplinaire analyse les contradictions croissantes observées dans la relation entre Etat et société dans les sociétés post-modernes et cherche à impulser, dans le domaine du droit public, un nouvel axe de réflexion intégrant mieux la dynamique sociétale. (ib) 